\title{
Divalent Cations Affect the Stability and Structure of Dad2p, a Subunit of the Candida Albicans Kinetochore Dam1 Complex
}

\author{
Jennifer Turner Waldo ${ }^{1}$, Tsering Dolma ${ }^{1}$ \& Emily Rouse ${ }^{1}$ \\ ${ }^{1}$ State University of New York at New Paltz, USA \\ Correspondence: Jennifer Turner Waldo, Biology Department, State Uniersity of New York at New Paltz, New \\ Paltz, NY, USA. Tel: 1-845-257-3698. E-mail: waldoj@newpaltz.edu
}

Received: April 14, 2016 Accepted: April 25, 2016 Online Published: April 30, 2016

doi:10.5539/jmbr.v6n1p26 URL: http://dx.doi.org/10.5539/jmbr.v6n1p26

\begin{abstract}
The heterodecameric Dam1 complex is involved in establishing and maintaining the connection between the kinetochore and the mitotic spindle during mitosis. Biochemical studies of the reconstituted complex have shed light upon how it interacts with microtubules. However, little information about the biochemical properties of the isolated subunits has been available. This report examines the stability and structure of Dad2p, one of the Dam1 complex subunits isolated from Candida albicans. By employing differential scanning fluorimetry, protease protection and hydrodynamic analyses, we show that Dad2p is specifically responsive to the presence of divalent cations. This observation may be important for understanding the dynamic structure and regulation of the Dam1 complex in fungal cells.
\end{abstract}

Keywords: Mitosis, kinetochore, Dam1 complex, Candida albicans

\section{Introduction}

The process of mitosis has been studied extensively. While many fundamental mysteries remain to be unraveled, traditional biochemical and cell biological studies, as well as more recent genomic and proteomic approaches have resulted in a rather lengthy list of protein players necessary for correct chromosome segregation (Gascoigne \& Cheeseman, 2011). Despite a tremendous amount of effort, the ability to reconstitute mitosis in vitro-the "gold standard" for a detailed biochemical understanding of the process-has been technically unfeasible (Akiyoshi \& Siggins, 2012). Therefore, unlike other fundamental cellular processes like DNA replication or transcription, our understanding of the detailed dynamics of the mitotic machinery remains comparatively limited.

Mitosis requires the formation of a highly regulated connection between the microtubules of the mitotic spindle and the DNA of each sister chromatid. This contact is mediated by the kinetochore, a dynamic protein complex that is assembled at epigenetically marked regions of the chromosome known as centromeres (Allshire \& Karpen, 2008). Scores of proteins have been identified as present in and important for kinetochore function (Gascoigne \& Cheeseman, 2011; Roy, Varshney, Yadav, \& Sanyal, 2013). An emerging portrait of the structure of the kinetochore includes an increasingly detailed understanding of the biochemical properties of several multi-protein complexes, including those that contact the DNA directly, and those that appear to solely function in binding to microtubules (Alushin \& Nogales, 2011).

Many groups, including our own, have focused on one of these kinetochore constituents, the Dam1 complex (also called the DASH complex) (Buttrick \& Millar, 2011). The Dam1 complex is involved in establishing and maintaining the connection between the chromosome and the mitotic spindle. It is comprised of ten different proteins, and was first identified in S. cerevisiae. Elegant biochemical and biophysical analyses have shown that multiple copies of the complex are capable of forming rings around microtubules in vitro (Miranda, De Wulf, Sorger, \& Harrison, 2005; Miranda, King, \& Harrison, 2007; Ramey et al., 2011; Wang et al., 2007; Westermann et al., 2005; Westermann et al., 2006). Although this structure provides a satisfying model which may explain how kinetochores remain tethered to the depolymerizing microtubule, the necessity for Dam1 encircling the microtubule in vivo remains somewhat controversial (Asbury, Gestaut, Powers, Franck, \& Davis, 2006; Grishchuk et al., 2008; Nogales \& Ramey, 2009; Westermann et al., 2006).

Interestingly, the ten proteins that make up this complex are absolutely required for cell survival in fungal species that employ a mechanism of attachment between the mitotic spindle and the kinetochore that involves a ratio of 1 
microtubule: 1 kinetochore. This is the case in S. cerevisiae (Cheeseman et al., 2001; Janke, Ortiz, Tanaka, Lechner, \& Schiebel, 2002; Li, Li, \& Elledge, 2005) and C. albicans (Burrack, Applen, \& Berman, 2011; Thakur \& Sanyal, 2011), but not so for S. pombe (Sanchez-Perez et al., 2005). This difference has been postulated to reflect the more stringent requirement for maintaining connection with the depolymerizing microtubule when a single point of attachment is present; thus, under these circumstances, the ring may provide necessary stability (Burrack et al., 2011; Thakur \& Sanyal, 2011). Outside of the yeasts, sequence-based homologues of the Dam1 complex proteins are not identifiable, though a variety of evidence suggests that the functional homologue in metazoans may be the Ska complex (Gaitanos et al., 2009; Guimaraes \& Deluca, 2009; Hanisch, Sillje, \& Nigg, 2006; Jeyaprakash et al., 2012; Welburn et al., 2009).

The internal structure of the Dam1 complex has been studied by electron microscopy (Miranda et al., 2005; Wang et al., 2007), sub-complex formation (Legal, Zou, Sochaj, Rappsilber, \& Welburn, 2016; Miranda et al., 2007) and yeast-two hybrid analysis (Ikeuchi, Nakano, Kamiya, Yamane, \& Kawarasaki, 2010; Shang et al., 2003). Together, these studies provide a low-resolution model of the Dam1 complex, which includes putative sites of interaction with the microtubule. In the commonly studied $S$. cerevisiae system, the ten individual proteins are not amenable to soluble expression in bacterial systems (J. Waldo \& Scherrer, 2008; Westermann et al., 2005), so the opportunity to study the complex using biochemical reconstitution and structural analysis of the subunits has not been available. We have been examining the individual subunits of the Dam1 complex from Candida albicans, as some of these proteins are capable of being expressed in bacteria. For example, the C. albicans Dadlp has been shown to behave as an intrinsically disordered protein when isolated (J. T. Waldo, Greagor, Iqbal, Gittens, \& Grant, 2010). Based on these studies, a working model is that Dad1p undergoes a structural transition upon binding to the other components of the complex.

This study examines another isolated subunit of the C. albicans Dam1 complex, Dad2p. Unlike Dad1p, the evidence presented here suggests that $\operatorname{Dad} 2 p$ is not a disordered protein, but that its stability and structure are altered by the addition of divalent cations. This insight may have implications for future work in developing in vitro Dam1 complex reconstitution, for considering how the activity of the complex may be regulated in vivo, and for guiding the development of novel anti-fungal compounds.

\section{Materials and Methods}

\subsection{Construction of Bacterial Expression Vectors}

The $C$. albicans DAD2 gene was cloned by PCR amplification of genomic DNA. PCR products were treated with the restriction enzymes BamHI and NgoMIV (New England Biolabs, Massachusettes, USA) and ligated into pST44-2 treated with the same enzymes (Tan, Kern, \& Selleck, 2005). Plasmids were verified by DNA sequencing (MWG Biotech, Texas, USA).

\subsection{Expression and Purification of Dad2p}

Gene expression was performed in BL21(DE3) E. coli cells grown in auto-inducing media (Studier, 2005). Cells were harvested by centrifugation at $4^{\circ} \mathrm{C}$, resuspended in Buffer A $(20 \mathrm{mMTris} \mathrm{pH} 7.5,500 \mathrm{mM} \mathrm{NaCl})$ and frozen at $-80^{\circ} \mathrm{C}$. Thawed cells were lysed by sonication and the clarified lysate was applied to a $10 \mathrm{ml}$ chelating-sepharose (GE Healthcare Lifesciences, New Jersey, USA) column charged with nickel sulfate. The column with developed with Buffer A supplemented with $300 \mathrm{mM}$ imidazole. Fractions containing the protein of interest were identified through SDS-PAGE, pooled and dialyzed overnight vs. $20 \mathrm{mM}$ Tris pH 7.5, 2.5 mM EDTA. The protein solution was centrifuged, applied to a $1 \mathrm{ml}$ MonoQ column and eluted with a linear gradient of $\mathrm{NaCl}$ ( 0 to .5M). Fractions containing protein were identified by SDS-PAGE, pooled and stored at $-80^{\circ} \mathrm{C}$. All chromatography steps were performed on an AKTA-FPLC (GE Healthcare Lifesciences, New Jersey, USA) at $4^{\circ} \mathrm{C}$.

\subsection{Differential Scanning Fluorescence}

Purified samples of Dad2p were incubated in a final volume of $20 \mu 1$, with various additives and Sypro Orange (Sigma Aldrich, Missouri, USA) at a final concentration of 5X. Samples were mixed and incubated at room temperature for 15 minutes prior to the addition of Sypro Orange. A CFX-96 RT-PCR system (BioRad, California, USA) was used to increase the incubation temperature of the samples from $20^{\circ} \mathrm{C}$ to $75^{\circ} \mathrm{C}$ at a rate of $1{ }^{\circ} \mathrm{C}$ per minute, taking a fluorescence reading every $0.2^{\circ} \mathrm{C}$ using a $\mathrm{LED} /$ photodiode set matched to the excitation and emission wavelengths of Sypro Orange. As the proteins unfold, Sypro Orange binds to the revealed hydrophobic amino acids and increases fluorescence emissions. Data was recorded using the included system software; the first derivative of the melting curves results in a negative peak, which is recorded as the protein's melting point. 
For assays in which the goal was to screen with a commercially available matrix, $5 \mu 1$ of each sample from Wizard Crystal Screen I (Rigaku, Texas, USA) was added to make the final volume $20 \mu$ l. For assays that explored the effect of different salts, $200 \mathrm{mM}$ of the indicated salt was used and the analysis was repeated 8 times.

\subsection{Protease Assays}

Samples contained $10 \mu \mathrm{g}$ Dad2p, $0.2 \mu \mathrm{g}$ thermolysin, $20 \mathrm{mM}$ Tris $\mathrm{pH} 7.5,50 \mathrm{mM} \mathrm{NaCl}$ and $500 \mathrm{mM}$ of additional salt solutions as indicated. Proteolysis took place during a 15 minute incubation at $30^{\circ} \mathrm{C}$ and was stopped with the addition of $0.2 \%$ SDS. Samples were visualized on a $15 \%$ SDS-PAGE stained with BioSafe Coomassie Stain (BioRad, California, USA).

\subsection{Size Exclusion Chromatography}

Samples of Dad2p containing $150 \mu \mathrm{g}$ protein were diluted 1:1 with column buffer containing either $20 \mathrm{mM}$ Tris $\mathrm{pH}$ 7.5, 2.5mM EDTA, $500 \mathrm{mM} \mathrm{NaCl}$; or $20 \mathrm{mM}$ Tris pH 7.5, 25mM NaCl, $500 \mathrm{mM} \mathrm{MgCl}_{2}$. Samples were applied to a Superdex 200 column (GE Healthcare Lifesciences, New Jersey, USA) equilibrated with the appropriate buffer at $4^{\circ} \mathrm{C}$. Protein standards (BioRad, California, USA) of 670, 158, 44, 17 and 1.35kDa were run under conditions identical to the experimental samples.

\subsection{Protein Concentration Determination}

Dad2p was incubated with or without $\mathrm{MgCl}_{2}$ for $15 \mathrm{~min}$ at the indicated temperatures in a final volume of $100 \mu 1$. Samples were removed and added to $200 \mu$ l Bradford Reagent (BioRad, California, USA) and absorbance was measured at $595 \mathrm{~nm}$. To calculate protein concentration, a standard curve generated with BSA was utilized. Alternatively, following incubation, protein concentration was determined by applying $2 \mu 1$ of sample to a Nanodrop (Thermo Fisher, Massachusettes, USA) spectrophotometer and monitoring absorbance at $280 \mathrm{~nm}$.

\section{Results and Discussion}

The Candida albicans DAD2 gene was placed in a pET-based expression plasmid and the protein was purified to homogeneity (Figure 1A). As a first step towards characterizing Dad2p, we utilized a high-throughput differential scanning fluorimetry (DSF) assay to rapidly screen for conditions and/or chemical additives that had a stabilizing effect on the protein. This assay uses the environmentally sensitive dye Syrpo Orange, which has been documented to fluoresce upon binding to hydrophobic residues on proteins (DeSantis, 2012; Niesen, Berglund, \& Vedadi, 2007; Vedadi et al., 2006). Following incubation, the protein samples were placed in an RT-PCR system that allowed the temperature to be slowly increased as fluorescence is monitored. As proteins denature, the signal from Syrpo Orange binding can be detected (Figure 1B). Analysis of these melting curves by calculating the first derivative of the fluorescence intensity plots allows a melting temperature $\left(T_{m}\right)$ to be determined (Figure 1C).

Hundreds of conditions can rapidly be tested in this manner in order to screen for molecules that affect a protein's structure. Results from a typical scan are presented in Figure 1D. The 48 conditions reported here are from the Rigaku Wizard I crystal screen kit. The red bars show how the $T_{m}$ of Dad2p changes as a result of incubation of the protein in each condition. An increase in $T_{m}$ is generally understood to be reflective of stabilization of the protein structure. Of the 48 experimental conditions presented here, four showed an increase in the $\mathrm{T}_{\mathrm{m}}$ greater than $4^{\circ} \mathrm{C}$. These were: \#23 (15\% ethanol, 200mM MgCl $100 \mathrm{mM}$ imidazole pH8.0), \#25 (30\% PEG-400, $200 \mathrm{mM} \mathrm{MgCl}$, $100 \mathrm{mM}$ Tris pH8.5), \#44 (30\% PEG-400, 200mM c, 100mM Sodium Acetate pH4.5) and \#40 (10\% isopropanol, 200mM Calcium Acetate, 100mM MES pH6.0). The identity of the other conditions tested can be found at www.rigakureagents.com. To illustrate the specificity of this assay, results from an identical run with lysozyme, a completely unrelated protein of similar size, are shown (blue bars in Figure 1D). As the profiles for Dad2p and lysozyme are markedly different from each other, there is no evidence that any of the Dad2p stabilizing conditions picked up in this screen work as non-specific protein stabilizers.

A unifying feature of the four conditions that were observed to specifically stabilize Dad2p is the presence of $\mathrm{MgCl}_{2}$ and Calcium Acetate, salts of similar ionic composition. Comparable results were seen in other screens as well (data not shown). In order to follow up on this observation, the individual components present in the four solutions were titrated into Dad2p and $\mathrm{T}_{\mathrm{m}}$ was determined. Addition of $\mathrm{MgCl}_{2}$ and Calcium Acetate clearly increased $\mathrm{T}_{\mathrm{m}}$ (Figures 2A,B), while the other additives found in the initial conditions, PEG-400, isopropanol and ethanol did not appreciably affect the $\mathrm{T}_{\mathrm{m}}$ (Figure 2C,D). Buffer composition and $\mathrm{pH}$ level also had no effect (data not shown). 

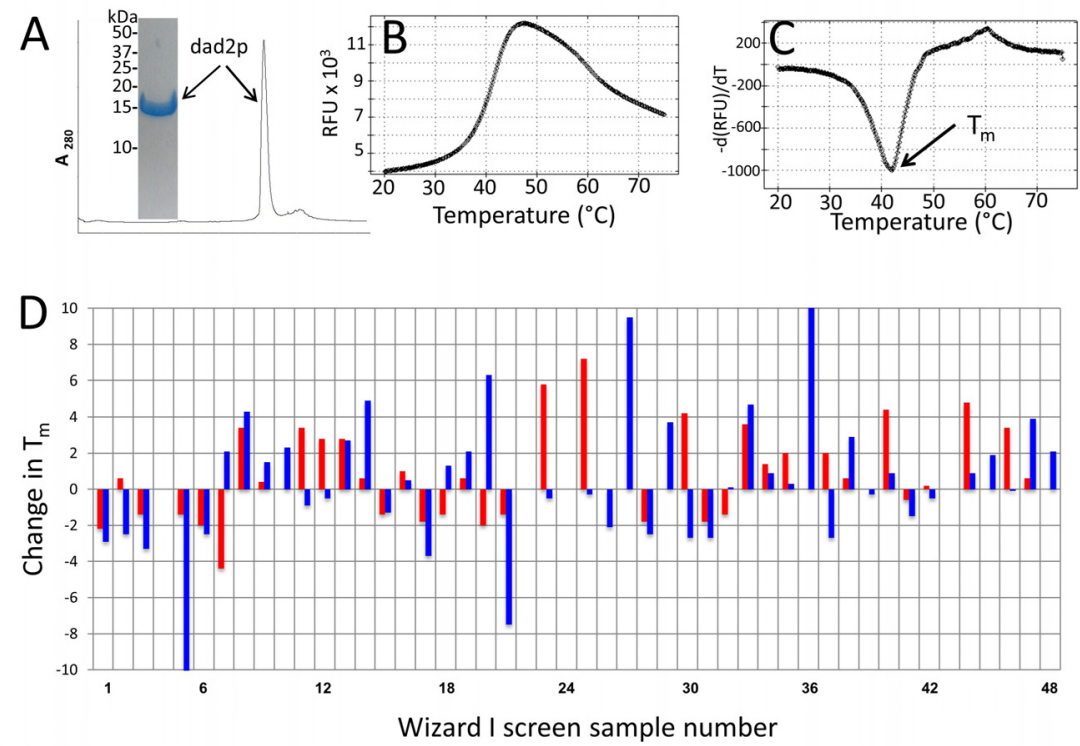

Figure 1. Screen for conditions that stabilize Dad2p. A) Following purification, Dad2p elutes as a single peak from a Superdex 200 gel filtration column, and runs as a single band on SDS-PAGE (insert). B) Fluorimetry assay with Dad2p. Samples were incubated with Sypro Orange and monitored for fluorescence upon increasing temperature. As the protein unfolds, fluorescence increases. C) The data in Panel B are replotted to include the first derivative of the fluorescence measurements. The minima reflects the melting point $\left(T_{m}\right)$. D) Samples of Dad2p (red bars) and lysozyme (blue bars) were incubated with the 48 solutions comprising a commercially available crystallization screen and $T_{m}$ of the protein was determined and compared to the $T_{m}$ of the protein in a solution containing only Tris buffer $(\mathrm{pH} 7.5)$ and $100 \mathrm{mM} \mathrm{NaCl}$
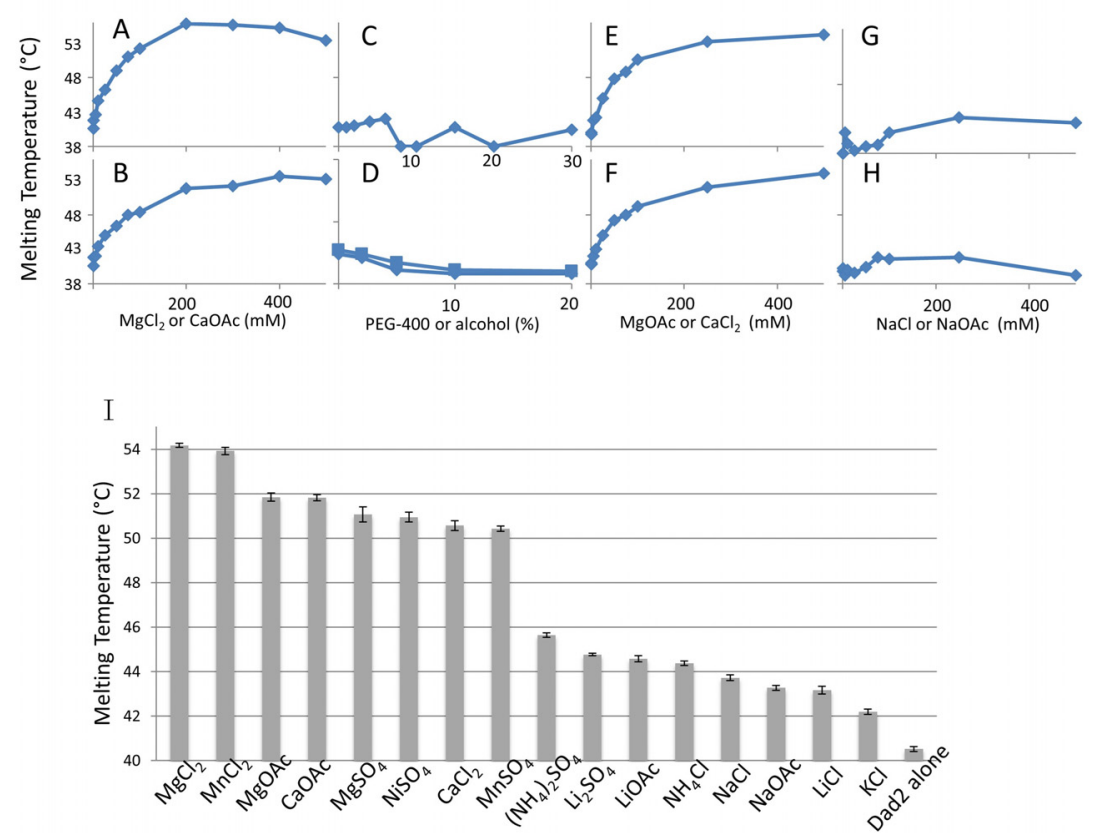

Figure 2. Melting temperature of Dad2p as a function of additive titration. Dad2p, Sypro Orange and the potentially stabilizing additives identified in Figure 1 were incubated prior to $T_{m}$ determination. Increasing amounts of A) $\mathrm{MgCl}_{2}$ and B) Calcium Acetate resulted in a higher $\mathrm{T}_{\mathrm{m}}$, while C) PEG-400 and D) ethyl (triangles) or isopropyl (squares) alcohol did not. Addition of $\mathrm{E}$ ) Magnesium Acetate and $\mathrm{F}$ ) $\mathrm{CaCl}_{2}$ increased $\mathrm{T}_{\mathrm{m}}$, but the monovalent salt solutions of G) $\mathrm{NaCl}$ and $\mathrm{H}$ ) Sodium Acetate did not. I) The melting point assay was repeated for a variety of salt solutions, each present at a final concentration of $200 \mathrm{mM}$ in a solution containing $20 \mathrm{mM}$ Tris $\mathrm{pH}$ 7.5. Each assay was repeated eight times, the values reported are mean $+/$ - SEM 
We next explored the specificity of the requirement for these salt solutions. Incubating Dad2p with Magnesium Acetate or $\mathrm{CaCl}_{2}$, effectively switching the cation and anion components of the salts described above, resulted in a similar increase in thermal stability (Figure 2E,F), indicating that the effect is not dependent upon the specific combination of anion and cation. However, monovalent cation salts with the same anion, $\mathrm{NaCl}$ and Sodium Acetate, did not elevate the $T_{m}$ (Figure $2 \mathrm{G}, \mathrm{H}$ ). Together these observations suggest that the specific agents responsible for the increased stability of Dad2p are the divalent cations $\mathrm{Mg}^{2+}$ and $\mathrm{Ca}^{2+}$.

To determine if other salts could similarly stabilize Dad2p, we performed the melting point assay in the presence of a variety of divalent and monovalent cation solutions (Figure 2I). The divalent cations magnesium, manganese, calcium, and nickel were shown to increase melting temperature more than the monovalent cations sodium, lithium, ammonium and potassium. Addition of iron, zinc, copper and cobalt solutions resulted in an inability to determine any melting point in this assay (data not shown). Therefore, there appears to be a general trend whereby divalent cations other than those initially identified impact the structure of $\operatorname{Dad} 2 p$ in a way that is measurably different than monovalent cations.

We next explored the ability of additional biochemical assays to detect, and thereby confirm, this effect. To visualize how the structure of Dad2p changes in the presence of divalent cations, we first employed a protease protection assay. Incubation of Dad2p with the broad-specificity protease thermolysin results in near complete degradation, with two distinct proteolytic fragments identifiable under these experimental conditions (blunt arrows, Figure 3A). When this assay is repeated in the presence of divalent cations $\left(\mathrm{Mg}^{2+}, \mathrm{Ca}^{2+}\right)$, there is a marked decrease in protease activity, while a monovalent cation solution $\left(\mathrm{Na}^{+}\right)$did not afford the same protection. As a control, cleavage of lysozyme was not impacted by the addition of any of these solutions (data not shown).
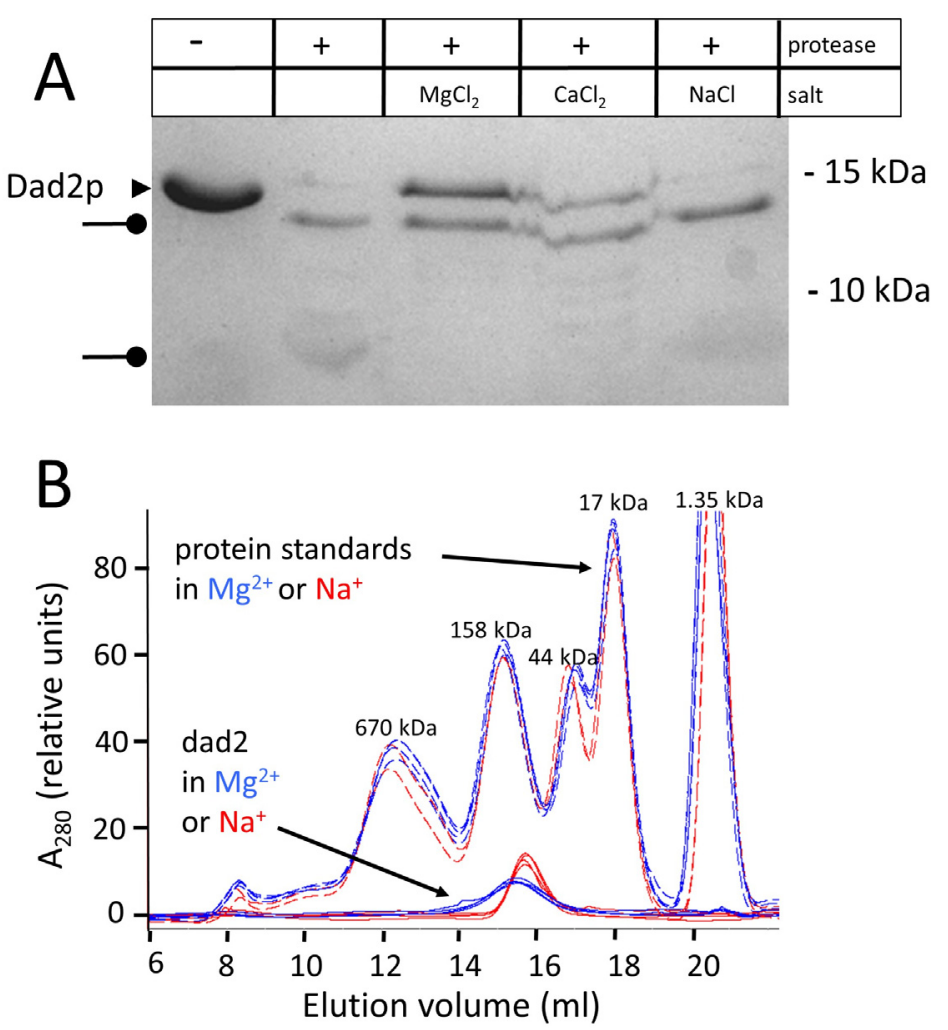

Figure 3. Protease sensitivity and hydrodynamic properties are also affected by divalent cations. A) Dad2p was incubated with or without the protease thermolysin and $500 \mathrm{mM}$ salt solutions as indicated. Protein fragments were analyzed in a Coomassie Blue stained SDS-PAGE. The arrow indicates the position of intact Dad2p, the blunt arrows indicate the position of proteolytic fragments. B) Samples of protein standards (dotted lines) and Dad2p (solid lines) were applied to a Superdex 200 gel filtration column in the presence of $500 \mathrm{mM} \mathrm{NaCl}$ (red traces) or $\mathrm{MgCl}_{2}$ (blue traces). Each samples was run in triplicate and all nine chromatograms are layered in this figure 
Next, the hydrodynamic properties of Dad2p were explored via a gel filtration assay. Figure 3B presents overlaid chromatograms of three repeats each of a set of protein standards (dotted lines) or Dad $2 p$ (solid lines) run with buffer containing $\mathrm{NaCl}$ (red traces) or $\mathrm{MgCl}_{2}$ (blue traces). Interestingly, purified $\mathrm{Dad} 2 \mathrm{p}$ elutes at a position significantly earlier than would be expected for the monomeric protein (observed molecular weight via gel filtration $\sim 120,000 \mathrm{Da}$, expected molecular weight $=14,000 \mathrm{Da}$ ). This may reflect either protein oligomerization or an extended or unusual protein conformation. In the presence of $\mathrm{MgCl}_{2}$, two things happen: there is a shift of the $\mathrm{Dad} 2 \mathrm{p}$ peak to a slightly earlier elution position, and the peak becomes noticeably spread out. Neither of these observations hold true for the protein standards, so this change in protein structure dependent upon $\mathrm{MgCl}_{2}$ addition appears to be specific to Dad2p.

While working with Dad2p we observed that the protein consistently gave lower protein concentration values than expected when using the Bradford reagent system. In particular, we found that boiling the protein resulted in a $\sim 500 \%$ increase in the protein concentration calculated from the Bradford readings as compared to the value calculated at room temperature, while a similar impact was not observed when protein concentration was determined by UV spectroscopy (Figure 4A). This suggests that the amino acids reactive with Bradford reagent (primarily Arginine) are concealed by the protein's tertirary or quaternary structure, and that this structure is not disrupted by low $\mathrm{pH}$ conditions ( $\sim 2$, in the Bradford reagent), but it is disrupted at high temperatures. In addition, the residues that typically react to result in absorbance at $280 \mathrm{~nm}$ (primarily Tryptophan and Tyrosine) must not be similarly concealed and revealed in a temperature-dependent manner.

To determine if this property would be affected by the presence of divalent cations, we incubated Dad2p at a variety of temperatures and then subjected the samples to Bradford quantitation over a series of increasing $\mathrm{MgCl}_{2}$ additions (Figure 4B). The Bradford reactivity increased as temperature was raised. The midpoint of these cures is analogous to the $\mathrm{T}_{\mathrm{m}}$ observed in the DSF assays. Increasing $\mathrm{MgCl}_{2}$ resulted in a shift of the curves to the right; thus, higher concentrations of $\mathrm{MgCl}_{2}$ are increasing the apparent melting temperature and reflect a stabilization of the protein's structure. Further, the $\mathrm{T}_{\mathrm{m}}$ observed in this experiment with Bradford reagent in the absence ( 40C) and the presence $(\sim 55 \mathrm{C})$ of divalent cations are virtually the same as those seen in the Sypro-Orange monitored DSF experiments.
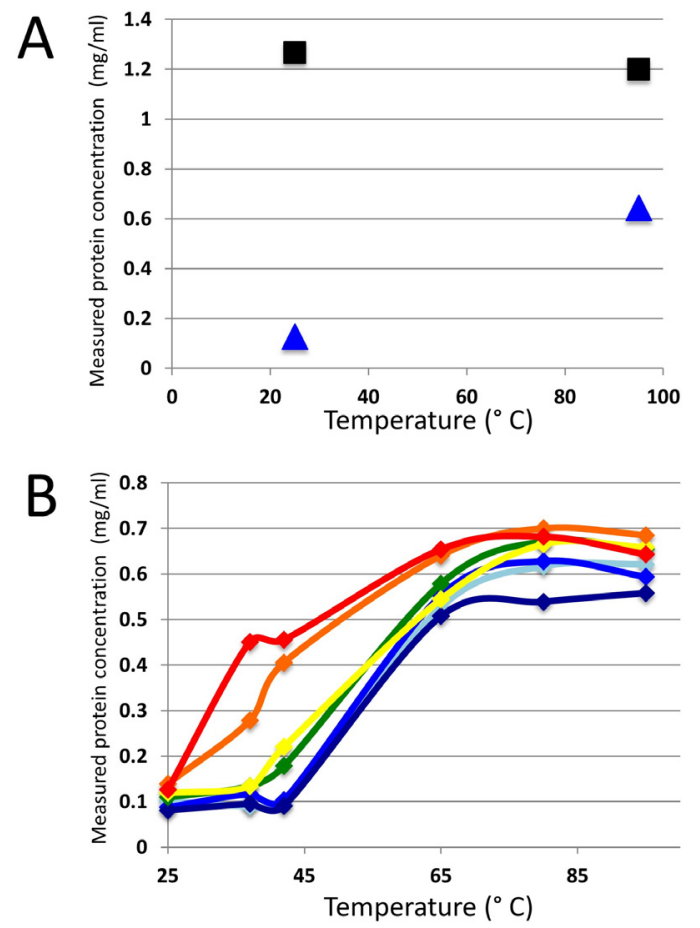

Figure 4. Temperature affects Dad2p reactivity with the Bradford reagent. A) Dad2p was incubated at room temperature or $100^{\circ} \mathrm{C}$ for 15 minutes. Aliquots were either added to Bradford reagent (blue triangles) or applied directly to a small-volume UV spectrophotometer (black squares) to determine protein concentration. B) Dad2p was incubated with $0 \mathrm{mM}$ (red), $50 \mathrm{mM}$ (orange), $75 \mathrm{mM}$ (yellow), $100 \mathrm{mM}$ (green), $150 \mathrm{mM}$ (royal blue), 250 $\mathrm{mM}$ (cyan), $500 \mathrm{mM}$ (indigo) $\mathrm{MgCl}_{2}$ at the indicated temperature for two minutes. Protein concentration was then determined by incubation with the Bradford reagent 
Taken together, the DSF experiments, protease protection assay, gel filtration analysis and Bradford reagent reactivity, confirm that the structure of Dad2p is specifically altered by the addition of divalent cations. The mechanism behind this observation remains to be elucidated. Sequence analysis does not provide any obvious metal binding motifs (data not shown), but analysis of the crystal structure, when available, may either reveal a co-crystallizing divalent cation, or provide the structural information necessary to mount a search for possible sites of interaction (Brylinski \& Skolnick, 2011). This observation should provide important information for the development of models for how the Dam1 complex may be regulated or assembled, as divalent cations have been shown to play important roles in other multi-protein complexes (Huet, Conway, Letellier, \& Boulanger, 2010; Rubin, 2007; Tiwari, Askari, Humphries, \& Bulleid, 2011; Weinreb et al., 2012).

In addition, this report provides an example of a relatively novel and practical way of uncovering fundamental biochemical and biophysical properties of a protein. Many labs have access to RT-PCR systems, and the utility of this approach should be of interest to many, as it doesn't require protein modification or antibody production.

\section{Acknowledgments}

This work was supported by an NSF MRI grant (1039966) and by a SUNY New Paltz Academic Year Undergraduate Research Experience (AYURE) Award.

\section{References}

Akiyoshi, B., \& Siggins, S. (2012). Reconstituting the kinetochore-microtubule interface: what, why, and how. Chromosoma, 121(3), 235-250. http://dx.doi.org/10.1007/s00412-012-0362-0

Allshire, R. C., \& Karpen, G. H. (2008). Epigenetic regulation of centromeric chromatin: old dogs, new tricks? Nat Rev Genet, 9(12), 923-937. http://dx.doi.org/10.1038/nrg2466

Alushin, G., \& Nogales, E. (2011). Visualizing kinetochore architecture. Curr Opin Struct Biol, 21(5), 661-669. http://dx.doi.org/10.1016/j.sbi.2011.07.009

Asbury, C. L., Gestaut, D. R., Powers, A. F., Franck, A. D., \& Davis, T. N. (2006). The Dam1 kinetochore complex harnesses microtubule dynamics to produce force and movement. Proc Natl Acad Sci U S A. http://dx.doi.org/10.1073/pnas.0602249103

Brylinski, M., \& Skolnick, J. (2011). FINDSITE-metal: integrating evolutionary information and machine learning for structure-based metal-binding site prediction at the proteome level. Proteins, 79(3), 735-751. http://dx.doi.org/10.1002/prot.22913

Burrack, L. S., Applen, S. E., \& Berman, J. (2011). The requirement for the Dam1 complex is dependent upon the number of kinetochore proteins and microtubules. Curr Biol, 21(10), 889-896. http://dx.doi.org/10.1016/j. cub.2011.04.002

Buttrick, G. J., \& Millar, J. B. (2011). Ringing the changes: emerging roles for DASH at the kinetochore-microtubule Interface. Chromosome Res, 19(3), 393-407. http://dx.doi.org/10.1007/s10577-011 $-9185-8$

Cheeseman, I. M., Brew, C., Wolyniak, M., Desai, A., Anderson, S., Muster, N., ... Barnes, G. (2001). Implication of a novel multiprotein Dam1p complex in outer kinetochore function. J Cell Biol, 155(7), 1137-1145. http://dx.doi.org/10.1083/jcb.200109063

DeSantis, K., Reed, A, Rahhal, R and Reinking, J. (2012). Use of differential scanning fluorimetry as a high-throughput assay to identify nuclear receptor ligands. Nuclear Receptor Signaling, $10(\mathrm{e} 002), 1-5$. http://dx.doi.org/10.1621/nrs.10002

Gaitanos, T. N., Santamaria, A., Jeyaprakash, A. A., Wang, B., Conti, E., \& Nigg, E. A. (2009). Stable kinetochore-microtubule interactions depend on the Ska complex and its new component Ska3/C13Orf3. EMBO J, 28(10), 1442-1452. http://dx.doi.org/10.1038/emboj.2009.96

Gascoigne, K. E., \& Cheeseman, I. M. (2011). Kinetochore assembly: if you build it, they will come. Curr Opin Cell Biol, 23(1), 102-108. http://dx.doi.org/10.1016/j.ceb.2010.07.007

Grishchuk, E. L., Spiridonov, I. S., Volkov, V. A., Efremov, A., Westermann, S., Drubin, D., ... McIntosh, J. R. (2008). Different assemblies of the DAM1 complex follow shortening microtubules by distinct mechanisms. Proc Natl Acad Sci U S A, 105(19), 6918-6923. http://dx.doi.org/10.1073/pnas.0801811105

Guimaraes, G. J., \& Deluca, J. G. (2009). Connecting with Ska, a key complex at the kinetochore-microtubule interface. EMBO J, 28(10), 1375-1377. http://dx.doi.org/10.1038/emboj.2009.124 
Hanisch, A., Sillje, H. H., \& Nigg, E. A. (2006). Timely anaphase onset requires a novel spindle and kinetochore complex comprising Ska1 and Ska2. EMBO J, 25(23), 5504-5515. http://dx.doi.org/10.1038/sj.emboj.760 1426

Huet, A., Conway, J. F., Letellier, L., \& Boulanger, P. (2010). In vitro assembly of the $\mathrm{T}=13$ procapsid of bacteriophage T5 with its scaffolding domain. J Virol, 84(18), 9350-9358. http://dx.doi.org/10.1128/JVI. 00942-10

Ikeuchi, A., Nakano, H., Kamiya, T., Yamane, T., \& Kawarasaki, Y. (2010). A method for reverse interactome analysis: High-resolution mapping of interdomain interaction network in Dam1 complex and its specific disorganization based on the interaction domain expression. Biotechnol Prog, 26(4), 945-953. http://dx.doi.org/10.1002/btpr.403

Janke, C., Ortiz, J., Tanaka, T. U., Lechner, J., \& Schiebel, E. (2002). Four new subunits of the Dam1-Duo1 complex reveal novel functions in sister kinetochore biorientation. EMBO J, 21(1-2), 181-193. http://dx.doi.org/10.1093/emboj/21.1.181

Jeyaprakash, A. A., Santamaria, A., Jayachandran, U., Chan, Y. W., Benda, C., Nigg, E. A., \& Conti, E. (2012). Structural and functional organization of the Ska complex, a key component of the kinetochore-microtubule interface. Mol Cell, 46(3), 274-286. http://dx.doi.org/10.1016/j.molcel.2012.03.005

Legal, T., Zou, J., Sochaj, A., Rappsilber, J., \& Welburn, J. P. (2016). Molecular architecture of the Dam1 complex-microtubule interaction. Open Biol, 6(3). http://dx.doi.org/10.1098/rsob.150237

Li, J. M., Li, Y., \& Elledge, S. J. (2005). Genetic analysis of the kinetochore DASH complex reveals an antagonistic relationship with the ras/protein kinase A pathway and a novel subunit required for Ask1 association. Mol Cell Biol, 25(2), 767-778. http://dx.doi.org/10.1128/MCB.25.2.767-778.2005

Miranda, J. J., De Wulf, P., Sorger, P. K., \& Harrison, S. C. (2005). The yeast DASH complex forms closed rings on microtubules. Nat Struct Mol Biol, 12(2), 138-143. http://dx.doi.org/10.1038/nsmb896

Miranda, J. J., King, D. S., \& Harrison, S. C. (2007). Protein arms in the kinetochore-microtubule interface of the yeast DASH complex. Mol Biol Cell, 18(7), 2503-2510. http://dx.doi.org/10.1091/mbc.E07-02-0135

Niesen, F. H., Berglund, H., \& Vedadi, M. (2007). The use of differential scanning fluorimetry to detect ligand interactions that promote protein stability. Nat Protoc, 2(9), 2212-2221. http://dx.doi.org/10.1038/nprot. 2007.321

Nogales, E., \& Ramey, V. H. (2009). Structure-function insights into the yeast Dam1 kinetochore complex. J Cell Sci, 122(Pt 21), 3831-3836. http://dx.doi.org/10.1242/jcs.004689

Ramey, V. H., Wang, H. W., Nakajima, Y., Wong, A., Liu, J., Drubin, D., ... Nogales, E. (2011). The Dam1 ring binds to the E-hook of tubulin and diffuses along the microtubule. Mol Biol Cell, 22(4), 457-466. http://dx.doi.org/10.1091/mbc.E10-10-0841

Roy, B., Varshney, N., Yadav, V., \& Sanyal, K. (2013). The process of kinetochore assembly in yeasts. FEMS Microbiol Lett, 338(2), 107-117. http://dx.doi.org/10.1111/1574-6968.12019

Rubin, H. (2007). The logic of the Membrane, Magnesium, Mitosis (MMM) model for the regulation of animal cell proliferation. Arch Biochem Biophys, 458(1), 16-23. http://dx.doi.org/10.1016/j.abb.2006.03.026

Sanchez-Perez, I., Renwick, S. J., Crawley, K., Karig, I., Buck, V., Meadows, J. C., ... Millar, J. B. (2005). The DASH complex and Klp5/Klp6 kinesin coordinate bipolar chromosome attachment in fission yeast. EMBOJ, 24(16), 2931-2943. http://dx.doi.org/10.1038/sj.emboj.7600761

Shang, C., Hazbun, T. R., Cheeseman, I. M., Aranda, J., Fields, S., Drubin, D. G., \& Barnes, G. (2003). Kinetochore protein interactions and their regulation by the Aurora kinase Ipllp. Mol Biol Cell, 14(8), 3342-3355. http://dx.doi.org/10.1091/mbc.E02-11-0765

Studier, F. W. (2005). Protein production by auto-induction in high density shaking cultures. Protein Expr Purif, 4l(1), 207-234. http://dx.doi.org/10.1016/j.pep.2005.01.016

Tan, S., Kern, R. C., \& Selleck, W. (2005). The pST44 polycistronic expression system for producing protein complexes in Escherichia coli. Protein Expr Purif, 40(2), 385-395. http://dx.doi.org/10.1016/j.pep.2004. 12.002 
Thakur, J., \& Sanyal, K. (2011). The essentiality of the fungus-specific Dam1 complex is correlated with a one-kinetochore-one-microtubule interaction present throughout the cell cycle, independent of the nature of a centromere. Eukaryot Cell, 10(10), 1295-1305. http://dx.doi.org/10.1128/EC.05093-11

Vedadi, M., Niesen, F. H., Allali-Hassani, A., Fedorov, O. Y., Finerty, P. J., Jr., Wasney, G. A., ... Edwards, A. M. (2006). Chemical screening methods to identify ligands that promote protein stability, protein crystallization, and structure determination. Proc Natl Acad Sci $U$ S A, 103(43), 15835-15840. http://dx.doi.org/10.1073/pnas.0605224103

Waldo, J. T., Greagor, S. A., Iqbal, A. J., Gittens, A. S., \& Grant, K. K. (2010). The Dad1 subunit of the yeast kinetochore Dam1 complex is an intrinsically disordered protein. Biochem Biophys Res Commun, 400(3), 313-317. http://dx.doi.org/10.1016/j.bbrc.2010.08.050

Waldo, J., \& Scherrer, M. (2008). Production and initial characterization of Dad1p, a component of the Dam1-DASH kinetochore complex. PLoS One, 3(12), e3888. http://dx.doi.org/10.1371/journal.pone. 0003888

Wang, H. W., Ramey, V. H., Westermann, S., Leschziner, A. E., Welburn, J. P., Nakajima, Y., ... Nogales, E. (2007). Architecture of the Dam1 kinetochore ring complex and implications for microtubule-driven assembly and force-coupling mechanisms. Nat Struct Mol Biol, 14(8), 721-726. http://dx.doi.org/10.1038/ nsmb1274

Weinreb, P. H., Li, S., Gao, S. X., Liu, T., Pepinsky, R. B., Caravella, J. A., ... Woods, V. L., Jr. (2012). Dynamic Structural Changes Are Observed Upon Collagen and Metal Ion Binding to the Integrin alpha1 I Domain. $J$ Biol Chem. http://dx.doi.org/10.1074/jbc.M112.354365

Welburn, J. P., Grishchuk, E. L., Backer, C. B., Wilson-Kubalek, E. M., Yates, J. R., 3rd, \& Cheeseman, I. M. (2009). The human kinetochore Skal complex facilitates microtubule depolymerization-coupled motility. Dev Cell, 16(3), 374-385. http://dx.doi.org/10.1016/j.devcel.2009.01.011

Westermann, S., Avila-Sakar, A., Wang, H. W., Niederstrasser, H., Wong, J., Drubin, D. G., ... Barnes, G. (2005). Formation of a dynamic kinetochore- microtubule interface through assembly of the Dam1 ring complex. Mol Cell, 17(2), 277-290. http://dx.doi.org/10.1016/j.molcel.2004.12.019

Westermann, S., Wang, H. W., Avila-Sakar, A., Drubin, D. G., Nogales, E., \& Barnes, G. (2006). The Dam1 kinetochore ring complex moves processively on depolymerizing microtubule ends. Nature, 440(7083), 565-569. http://dx.doi.org/10.1038/nature04409

\section{Copyrights}

Copyright for this article is retained by the author(s), with first publication rights granted to the journal.

This is an open-access article distributed under the terms and conditions of the Creative Commons Attribution license (http://creativecommons.org/licenses/by/3.0/). 